\title{
FORMER FARM BUILDINGS REUSED AS RURAL VILLA, BUILDING CONTRACTOR OR GARDEN CENTRE: CONSEQUENCES FOR TRAFFIC FLOWS ON MINOR RURAL ROADS IN A CHANGING COUNTRYSIDE
}

\author{
Rinus F. Jaarsma ${ }^{1}$, Jasper R. de Vries $^{2}$
}

Received 13 April 2012; Accepted 22 October 2012

\begin{abstract}
Agricultural production is on a larger scale than ever before. With fewer holdings, current agricultural production leaves former farm buildings (FFBs) unused and available for new economic functions. This has consequences for traffic on minor rural roads and may conflict with a new societal demand for recreational activities in today's multifunctional rural space. Considering this, we explore the ability of the rural road network to absorb the newly generated traffic flows from FFBs. To do this, we investigate four underlying questions: (1) what are in practice the new economic functions of FFBs; (2) how can their traffic generation be estimated; (3) what is the capacity of the network of minor rural roads; and (4) how does spatial planning operate in this field? Specific statistical data are lacking, but research in Belgium and the Netherlands shows that redundant farm buildings have been changed to a residential or a non-agrarian activity, mostly belonging to the service sector of the economy. For most of these functions general trip rates are available. The new traffic generation strongly depends on the type of function. Commercial functions tend to considerably increase local traffic flows, including freight. Spatial planning should be alert for this. The capacity limits for minor rural roads must be respected to avoid damage to road and/or verge - prevention is better than cure!
\end{abstract}

Keywords: traffic and transportation, abandoned farm buildings, farmsteads, rural transition, minor rural roads, land use planning, spatial planning, traffic generation

Abstract: Ontwikkelingen in de landbouw en hergebruik van voormalige boerderijen: gevolgen voor verkeer op plattelandswegen in een veranderend buitengebied. Door schaalvergroting in de landbouw daalt het aantal bedrijven en komen voormalige boerderijen vrij voor nieuwe economische functies. Dit leidt tot nieuw verkeer op plattelandswegen. Dat kan conflicteren met de huidige maatschappelijke behoefte aan recreatieve activiteiten in het multi-functionele buitengebied. Tegen

\footnotetext{
${ }^{1}$ C. F. (Rinus) Jaarsma, independent consultant rural traffic and transportation. Belmontelaan 5, 6703 EC Wageningen, The Netherlands. Email: rinus.jaarsma@kpnmail.nl

2 J. R. (Jasper) de Vries, research assistant, Land Use Planning chair, Wageningen University, P.O. Box 47, 6700 AA Wageningen, The Netherlands. Email: jasper.devries@wur.nl
} 
deze achtergrond onderzoeken wij of het netwerk van plattelandswegen in staat is om het nieuw gegenereerde verkeer op te vangen. Daartoe wordt ingegaan op 4 achterliggende vragen: (1) wat zijn de nieuwe functies; (2) hoe kan de verkeersgeneratie worden bepaald; (3) wat is de capaciteit van plattelandswegen; (4) welke rol speelt ruimtelijke ordening hierbij. Er blijken geen systematische statistische gegevens te zijn, maar onderzoek in Nederland en Vlaanderen laat zien dat voormalige boerderijen een woonfunctie hebben gekregen of worden gebruikt voor niet-agrarische activiteiten, meestal uit de dienstensector van de economie. Voor de meeste functies zijn algemene kengetallen voor de verkeersgeneratie gepubliceerd. Commerciële functies kunnen de plaatselijke verkeersstromen sterk verhogen, ook die van vrachtverkeer. Dit punt verdient aandacht vanuit de ruimtelijke planning. De capaciteit van plattelandswegen moet in acht worden genomen om bermschade en schade aan de weg zelf te voorkomen - voorkomen is beter dan repareren!

Trefwoorden: verkeer en vervoer, voormalige boerderijen, rurale transitie, plattelandswegen, ruimtelijke ordening, ruimtelijke planning, kengetallen verkeersgeneratie

\section{Introduction}

The European countryside is continuously changing (Murdoch et al., 2003), especially with regard to agriculture. Within the current globalization process, agricultural production is occurring in a 'production landscape' on a much larger scale than ever before with less holdings in the same area. This concentration and intensification of agriculture leaves former farm buildings (FFBs) unused (Bindraban and Rabbinge, 2011). At the same time the countryside is becoming a multi-functional 'consumption' space where recreation, tourism and agritourism are developing on a large scale (Jongeneel and Slangen, 2004). As such, "the countryside is increasingly an area of consumption as well as production .... Alternative uses of rural space are developing..." (Ilbary, 1998; p.1). FFBs play an important role in this development, either as historical buildings heritage in a consumption area or as re-used facilities for new nonagricultural economic functions in a production area (CIGR, 1996).

Recent studies on FFBs focus on several items such as FFB impact on landscape (Van der Vaart, 2005), FFB suitability for reuse (Garcia and Ayuga, 2007), FFB architectural features (Fuentes, 2010) and a survey method to describe the actual use of FFBs by non-agricultural entrepreneurs (Verhoeve et al., 2012). While the reuse of FFBs gives added values to the landscape and supports the local economy, it also generates new traffic flows. Compared with traditional farm-bound flows, reuse of FFBs may continuously increase traffic volumes and/or cause another mix of modes on the network of minor rural roads (MMRs), depending on the specific new economic function of the abandoned farm building and the users it attracts. In redeveloping this area, land use planners and transportation engineers must understand that the road network around FFBs has historically been developed mainly or even exclusively for agricultural use and may not be able to cope with expanding traffic flows. Moreover, expanding flows may even detract from the attractiveness of these road network "capillaries" for recreational activities (Murdoch et al., 2003), especially those activities on foot or by bicycle (Jaarsma and Van Dijk, 2005).

To our knowledge, the impact of FFBs on rural traffic flows has not received much attention in the international literature. For this reason, this paper explores the ability of the rural road network to absorb the newly generated traffic flows on FFBs. In our examination we investigate four underlying research questions:

(1) What are the new economic functions for FFBs?

(2) How can the specific traffic generation of these functions be estimated?

(3) What is the capacity of the minor rural road network?

(4) How does spatial planning operate in this field? 
In the next section we present the research methods applied, followed by a section with results. We then place our findings in a wider context in a final discussion and conclusion section.

\section{Conceptual framework and research methods applied}

This section starts with a wider conceptual model for agricultural developments involving rural traffic. We then explain the methods applied in answering the research questions.

\subsection{Conceptual framework}

"The European countries heavily supported agricultural development after the Second World War to guarantee food supply." (Bindraban and Rabbinge, 2011: 86). To enable increasingly higher yields on continuously larger farms, small scale landscapes were drastically adjusted to modern farming practices after the 1950s. However, the high production levels created surpluses in the EU as well as environmental and budgetary problems. Therefore, in the mid1980s a process of agricultural policy reform started "leading to a shift of agricultural support from traditional price supply to direct income payments and set-aside requirements" (Jongeneel and Slangen, 2004). This line was continued through the $21^{\text {th }}$ century, as became clear in 2003. At that time the European Model of Agriculture (EMA) was introduced to integrate environmental goals into the common European agricultural policy and to develop the 'countryside stewardship' role of European farmers (Robinson, 2004). With the EMA, 'multifunctionality' (besides growing food, farmers took up all kinds of non-traditional side activities) became a leading catchword in EU-agricultural policy (Jongeneel and Slangen, 2004). Within the EMA policy farmers look for new financial resources and take different decisions to increase their revenues. The three most common ones are widening, enlarging of scale and terminating active farming. Figure 1 shows these possible decisions and the related consequences for rural traffic and transportation.

This article focusses on the farm buildings reused for new economic activities, the 'new' traffic these activities generate and how this traffic replaces the former agricultural farm-bound traffic (consequence $A$ in Figure 1). The consequences for the traffic to the farmland of the terminating farmer also have to be dealt with. These consequences strongly depend on the new land use, either agricultural or non-agricultural. For example, when the freed up land is used for intensive non-agricultural land uses, such as urban development, a new road lay-out will usually be designed to cope with the increased traffic. In contrast, the actual road network may facilitate the reuse of the same land as a nature development area because that land use actually reduces the traffic generation of the area compared with the former more transportationintensive agrarian traffic generation (consequence B). However, as stated before, land use statistics show that most of the freed up farmland is added to other farm enterprises. This enlargement of scale changes farm-bound traffic flows (consequence $\mathrm{C}$ ). For dairy farming this is elaborated by Rienks et al. (2009). Figure 1 further shows how the third possible land-reuse decision, widening into multifunctional agriculture, generates additional traffic to existing farms (consequence D). This generation will be elaborated on by Jaarsma et al. (in preparation).

As stated in the introduction, these widening and production developments in agriculture appear simultaneously: the 'dual agricultural pathway' for Europe (Bindraban and Rabbinge, 2011). Our approach when investigating the consequences for rural transportation is to first consider the developments $A-D$ separately and then to integrate them into the wider context of the developing countryside in a final study (forth coming). 


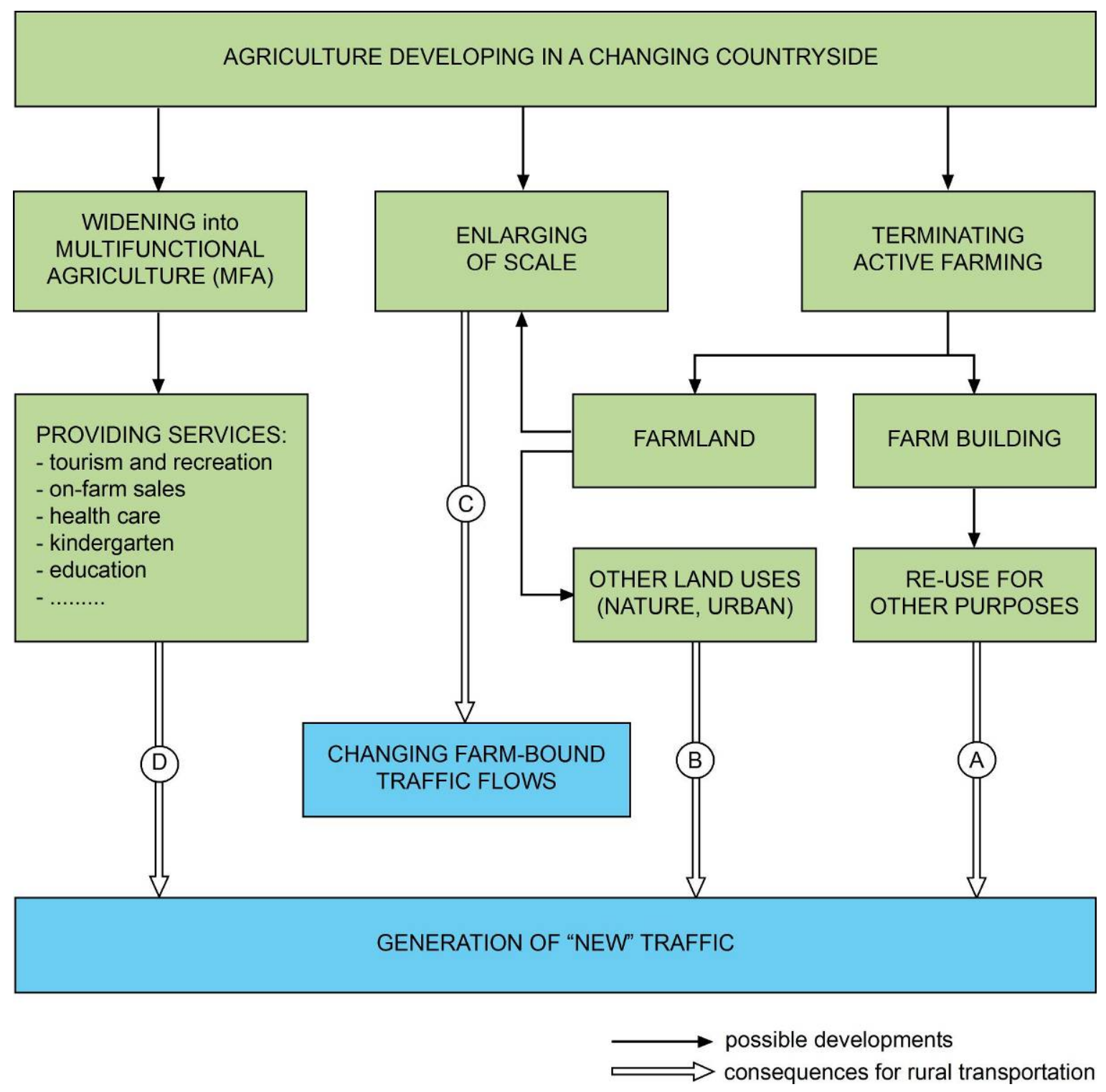

Fig 1. Three possible decisions by a farmer in a developing agriculture and their consequences for rural traffic and transportation.

\subsection{Research methods applied}

In this paper, we explore arrow $A$ in Figure 1 through a study of international literature. To estimate the traffic generated by reused FFBs, we apply a well-known method in transportation engineering: trip generation as caused by specific economic functions (land uses). This method was developed in the USA (ITE, 1979). On the basis of empirical research, this method presents average daily trip rates per unit (square meter floor space, inhabitant, worker, etc.) for a wide range of different land uses and activities. However, traffic generation depends on local situations. To apply the model to the Netherlands, we used Dutch data on traffic generation (CROW, 2007 and 2008). While these data are less detailed than the data for the USA, they nevertheless enable us to show ranges of volumes generated by the most common new functions for FFBs. Next, we investigate to what extent the volumes can be facilitated by the present infrastructural network. For this we use technical information on road capacity as applied to MRRs in Dutch land development projects (Mooy, 1981). Aspects of land use planning are relevant for this discussion because spatial legislation controls the legal state of activities in the rural area, including FFBs. We will illustrate this by showing the consequences of a change in Dutch spatial legislation for rural areas. 


\section{Results}

This section starts by exploring the cause of FFBs, i.e., the decreasing number of agricultural enterprises leaving farm buildings redundant and potentially suitable for new economic functions. We then focus on traffic generation created by these new functions and the capacity of the road network to absorb the new generated flows. Finally, we consider the role of land use planning and then illustrate this with an example.

\subsection{New functions}

To our knowledge, no general statistics on FFBs exist. To develop a rough idea of the number of farm buildings currently becoming redundant, we consider the development of the number of agricultural enterprises over time. As part of a structural change in European agriculture, the number of agricultural enterprises has enormously decreased over the last 50 years. For the Netherlands, Van der Vaart (2005) found a decline from 410,000 in 1950 to 92,800 in 2001. Similarly, more recent agricultural figures - these dealing with dairy farms in $6 \mathrm{EU}$ countries also show a decline between 1990 and 2005, and a further decline in 3 of the 6 countries from 2005 to 2007 (Figure 2).

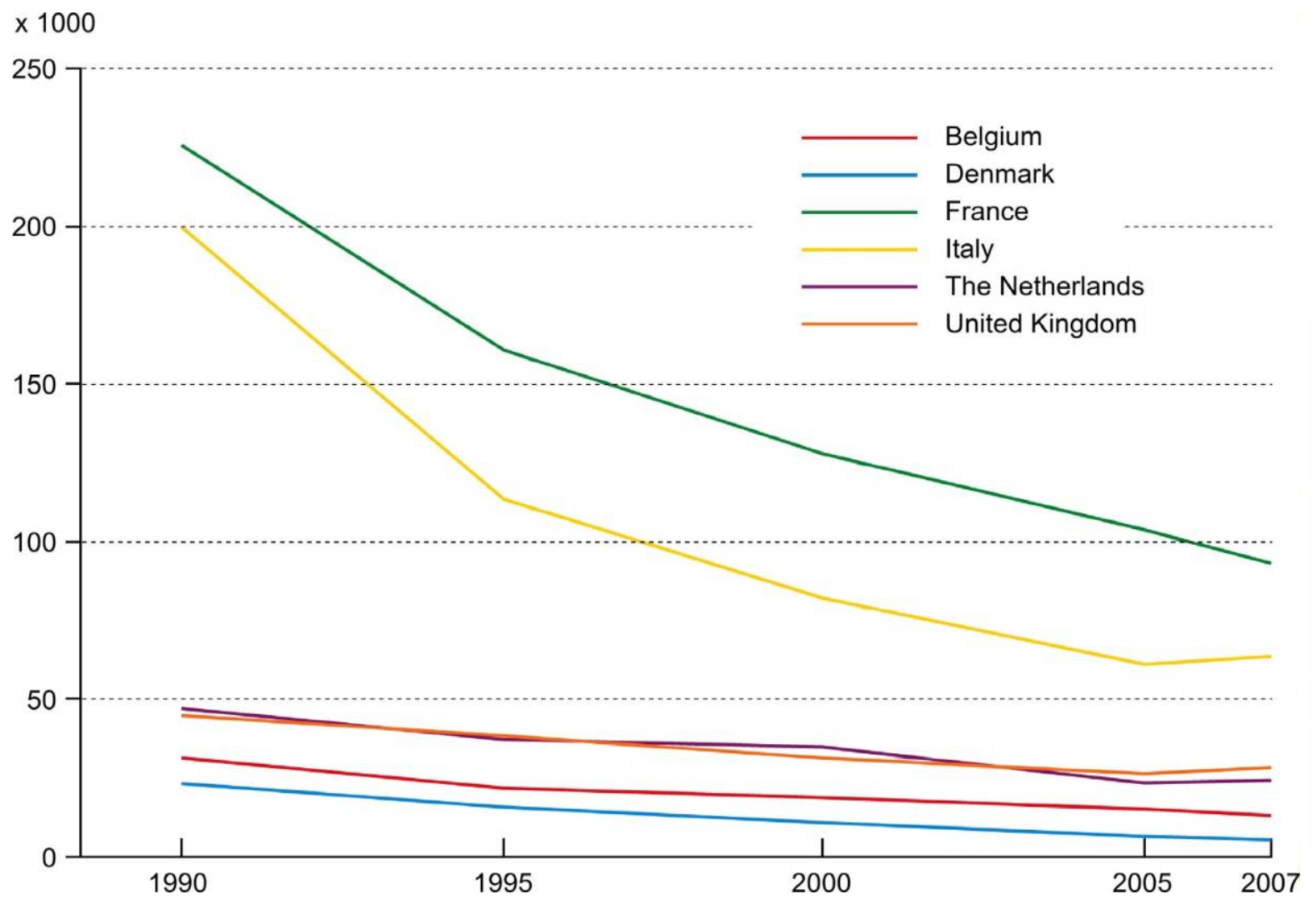

Fig 2. Fall in the number of farm enterprises 1990-2007 (dairy farming in $6 \mathrm{EU}$ countries), as a rough estimate of the number of abandoned farm buildings.

When the absolute numbers are expressed in indices, where $1990=100$, the indices in 2007 vary from 23 (in Denmark) to 63 (in the UK). Despite some 'flattening' in 2006 and 2007, the downward trend is expected to continue. For dairy farming in the Netherlands, only 10,000 farms are expected to exist in 2020 down from 22,000 enterprises in 2006 (CBS, 2007). In addition to falling into disuse, farm buildings also become unsuitable for agricultural use through a process of modernization or specialization in agriculture (Birkkjaer and Pedersen, 1996). These processes further increase the potential number of redundant farm buildings.

Specific statistical data to quantify the number of FFBs are lacking (Verhoeve et al., 2012). In the Netherlands, a substantial number of these buildings have survived with a functional change to a residential or a non-agrarian activity (Van der Vaart, 2005). Reports from Dutch provinces indicate that, at the beginning of this century, at least half of the farm buildings in 
the Netherlands had been converted into farms without farmers. These figures were even higher in regions that used to have a large number of small farms (Van der Vaart, 2005). In a 1994 field survey in seven municipalities covering one third of the Dutch province of Friesland, this author found that, in most cases, farms were changed into residences (85\%).The remaining non-agrarian use, mostly belonging to the service sector of the economy, was combined with a residence in $93 \%$ of the cases. Unoccupied farm buildings hardly existed. Verhoeve et al. (2012) present a survey method for describing and quantifying the reuse of FFBs by nonagricultural entrepreneurs. They found 1015 addresses housing a non-agricultural activity, 35\% of which were located in FFBs, in two districts $\left(605 \mathrm{~km}^{2}\right.$ and 234,000 inhabitants) in the Belgian province West Flanders. The most common activities in the FFBs were building contractors, trade or commercial companies, landscapers, transport and woodworking companies.

The Europe-wide fall in the number of farm enterprises also generally affects the rural economy and especially the rural processing agricultural industry. This decline also makes redundant the area's traditional buildings, such as flour mills, old wineries, slaughterhouses, warehouses and machinery garages (Garcia and Ayuga, 2007). When these kinds of buildings are reused, the consequences for rural traffic and transportation can be considered similar to those proposed for FFBs in this article.

In conclusion, quantitative national data are lacking, but research in the Netherlands and Belgium show that redundant farm buildings have been changed into a residential or a nonagrarian activity, most of which belong to the service sector of the economy.

\subsection{Traffic generation}

In this section we estimate traffic generation by a residence function and some non-agrarian activities as encountered in FFBs. To start, we estimate the 'level of reference': the traffic generated by a farm.

To our knowledge, no actual general data on commercial traffic generated by farms are available in literature. Historical data, for example from Flach (1966) for dairy farms, are now totally superseded by later developments. However, this is less a problem than it seems at first since trucks and agricultural vehicles, on the scale of the rural area, are still using the rural roads on their way -- not to the FFB as in the past-- but to the neighboring enlarged farms. We therefore conclude that the commercial trip generation is determined by the area of cultivated land, not by the number of farms. Trip generation of the farm residents can be compared with general trip rates in the Netherlands: roughly 7 trips by car per day per residence (CROW, 2007). However, farmers do not use their cars for commuting. We therefore presume that their trip rate is roughly 2 trips by car per day less. This difference results in a residential trip rate of 5 car trips per day per farm.

As stated in the previous paragraph, trip rates by residential function in the Netherlands are given in CROW (2007) and depend on the location of the residence. For rural areas, a general value of 7.4 is given (Table 4, page 19). This value is the average for all days of the week, i.e., $90 \%$ of the weekday average of 8.2 trips per residence. The contribution of freight traffic to this generation is extremely low: only 0.02 truck movements per residence per weekday. Compared with the farm family in the FFB, we expect a generation increase of roughly 2 car trips per weekday per residence for commuting.

When another new economic function besides a residence function is established on the FFB location, then the double question arises (1) which non-agrarian function does the FFB have, and (2) what trip generation does the FFB create. The literature in the previous section shows a wide range of functions. In Table 1, we use the categorization of the Flemish study (Verhoeve et al., 2012) as much as possible combined with the associated trip rates distinguished by location (urban centre, outskirts, rural area) given by CROW (2008). Unfortunately, not all functions are explicitly given in the 2008 study. For this reason, we use more general data from CROW (2007) for commercial areas and offices. 


\begin{tabular}{|c|c|c|}
\hline Function $^{1)}$ & $\begin{array}{l}\text { Daily trip generation and } \\
\text { unit (movements) }\end{array}$ & Remarks and sources \\
\hline $\begin{array}{l}\text { Building contractor; } \\
\text { transport; woodworking } \\
\text { company; garage; } \\
\text { metalworking company; } \\
\text { storage facilities; } \\
\text { groundworks contractor; food } \\
\text { manufacturer }{ }^{2)}\end{array}$ & $\begin{array}{l}170 \text { cars and } 44 \text { trucks } \\
\text { per } 10,000 \mathrm{~m}^{2}\end{array}$ & $\begin{array}{l}\text { Generation for mixed } \\
\text { commercial areas (CROW, } \\
\text { 2007; Table 8) }\end{array}$ \\
\hline $\begin{array}{l}\text { Trade or commercial } \\
\text { company }\end{array}$ & $\begin{array}{l}30 \text { motor vehicles per } \\
100 \mathrm{~m}^{2} \text { gross floor } \\
\text { space; } \\
75 \text { motor vehicles per } \\
100 \mathrm{~m}^{2} \text { gross floor space } \\
\text { 3) }\end{array}$ & $\begin{array}{l}\text { First value for DIY stores } \\
\text { (Dutch: bouwmarkten; CROW, } \\
\text { 2008; Table 1); second value for } \\
\text { brown and white good stores } \\
\text { (CROW, 2008; Table 4) }\end{array}$ \\
\hline Landscapers & $\begin{array}{l}37 \text { motor vehicles per } \\
100 \mathrm{~m}^{2} \text { gross floor space } \\
\text { (inside only) }\end{array}$ & $\begin{array}{l}\text { CROW (2008), Table } 2 \text { (garden } \\
\text { centre) }\end{array}$ \\
\hline Office $^{2)}$ & $\begin{array}{l}8 \text { motor vehicles per } 100 \\
\mathrm{~m}^{2} \text { gross floor space }\end{array}$ & $\begin{array}{l}\text { Generation for administrative } \\
\text { and business offices (CROW, } \\
2007 \text {; Table 10) }\end{array}$ \\
\hline Hairdressing salon & unknown & \\
\hline Wellness & $\begin{array}{l}32 \text { motor vehicles per } \\
100 \mathrm{~m}^{2} \text { gross floor space }\end{array}$ & $\begin{array}{l}\text { CROW (2008), Table } 19 \text { (fitness } \\
\text { centre) }\end{array}$ \\
\hline (Para)medical practice & $\begin{array}{l}26 \text { motor vehicles per } \\
100 \mathrm{~m}^{2} \text { gross floor space } \\
\text { or } 29 \text { motor vehicles per } \\
\text { doctor }\end{array}$ & $\begin{array}{l}\text { CROW (2008), Table } 51 \text { (family } \\
\text { doctor practise, single or } \\
\text { multiple) }\end{array}$ \\
\hline
\end{tabular}

1) Categories of non-agricultural activities in Verhoeve et al. (2012), Table 1.

2) For these functions, only a general value for weekdays is available. Source: CROW (2007).

3) Location on the outskirts of a town; no value is given for a location in a rural area.

$T a b$ 1. Traffic generation for several non-agrarian functions (trip rates: daily number of motor vehicle movements, all days of the week).

In conclusion, where redundant farm buildings have been changed to a residential function, a modest increase of traffic generation with 2 trips per day is plausible. For other non-agrarian economic functions, traffic generation strongly depends on the type of activity in the FFB. Commercial functions, such as garden centres with an estimated generation of 37 vehicle trips per $100 \mathrm{~m}^{2}$ gross shop surface, tend to considerably increase local traffic flows. Retail and transportation functions also significantly increase freight traffic. For some functions, information on trip rates is lacking or is only available for urban areas. 

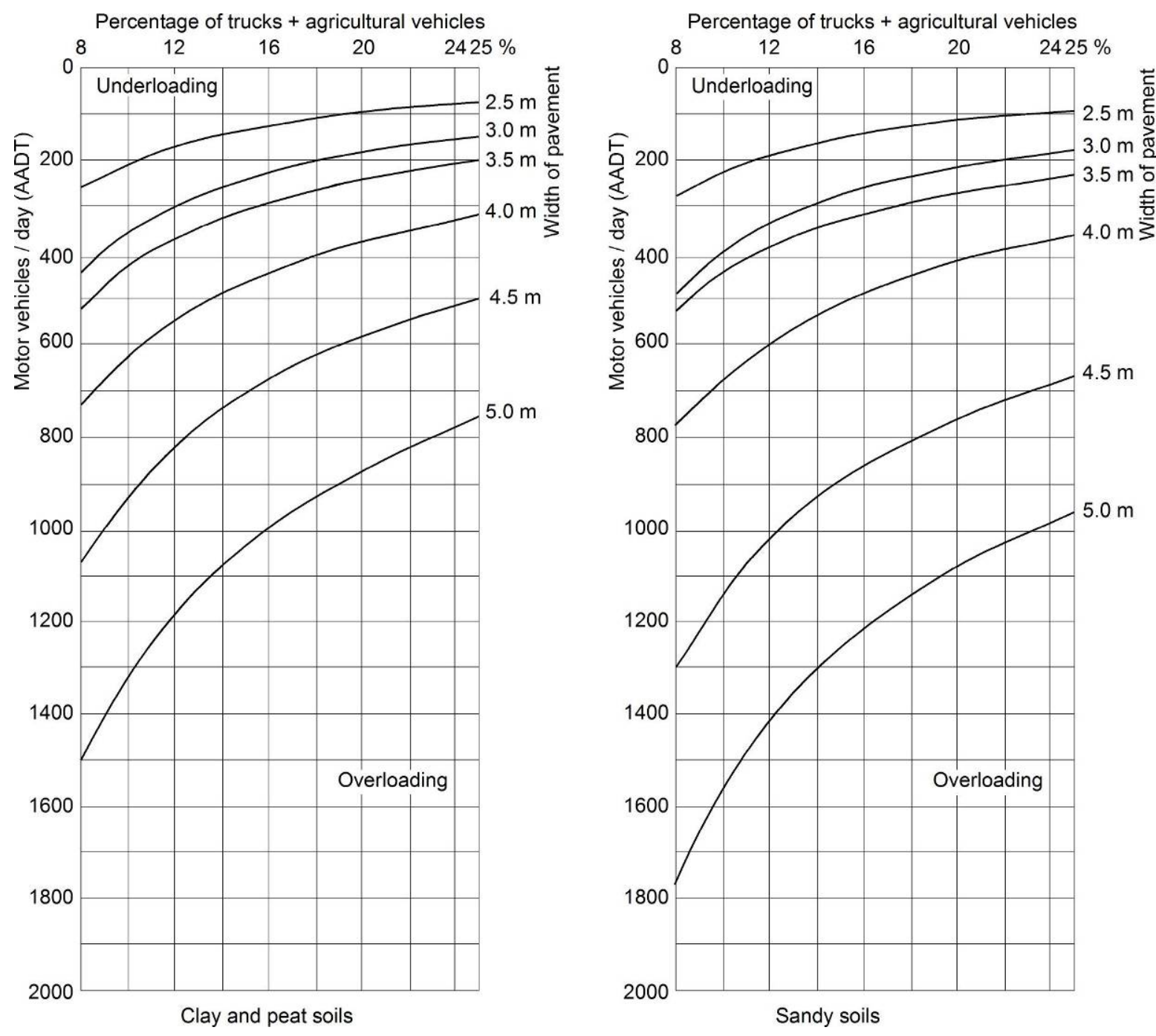

How to use this nomogram to find a pavement width, given the characteristics of traffic:

1. Consider the soil at the location and select the relevant panel.

2. Draw a horizontal line at the level of the road's AADT.

3. Draw a vertical line at the level of the road's proportion trucks + agricultural vehicles.

4. From the point where both straight lines meet, find the first curved line below this point. (each curved line in the panel represents an equal road capacity).

5. On the right-hand side of this curved line, the pavement width is given.

6. If the point where both straight lines meet is below the capacity line for a pavement width of $5.00 \mathrm{~m}$, a pavement width of $5.50 \mathrm{~m}$ is proposed.

\section{Example}

Given a situation with AADT $=800$ and $14 \%$ of the traffic being trucks and agricultural vehicles, then the necessary road width to prevent damage to the verge is $5.00 \mathrm{~m}$ in a clay or peat area (left panel) and $4.50 \mathrm{~m}$ for a sandy soil (right panel).

Fig 3. Required pavement widths $(2.5$ - $5.5 \mathrm{~m}$, incremental steps $0.5 \mathrm{~m})$ for minor rural roads, as a function of average annual daily traffic volume (AADT) and percentage of trucks and agricultural vehicles in total traffic for clay and peat soils (left panel) and sandy soils (right panel). Criterion: avoiding damage to the verge. Source: Mooy (1981). 


\subsection{Road capacity rural roads and minor rural roads}

The rural road network consists of dual carriage motorways, rural highways (one carriageway, two lanes) and minor rural roads (MRRs). Most farms and, as such, most FFBs are accessible by MRRs. MRRs have only one lane with a pavement width between 2.5 and $5.5 \mathrm{~m}$ for two-way traffic. MRRs show a mix of road users (cyclists, cars, trucks, and agricultural vehicles), a mix of speed profiles and a mix in vehicle masses. The combination of these different factors results in a relatively high risk of casualty accidents (Jaarsma et al., 2011). In the Netherlands, the majority of the MMRs (with a total length of $47,500 \mathrm{~km}$ ) have a pavement width of less than $4.00 \mathrm{~m}$. As a consequence, motor vehicles must use the verge both when encountering and when overtaking each other. The frequency of these events depends on pavement width (the smaller the pavement, the higher the frequency), traffic volume, and because of their larger dimensions, the proportion of trucks and agricultural vehicles in total traffic on the MRR. Empirical studies by the former Dutch Government Service for Land and Water Use quantified frequencies of acceptable usage levels of the verge, i.e., frequencies that do not damage the verge over the long term. These levels depend on the load capacity of the subsoil. Therefore, differences appear between areas with solid sandy soils and areas with weaker peat or clay soils. Figure 3 shows the capacity for MRRs.

For standardization, incremental steps of $0.50 \mathrm{~m}$ are applied in Figure 3 with a maximum of $5.50 \mathrm{~m}$. The latter pavement width is wide enough to avoid damage to the verge and allows for an AADT of 3,000 to 4,000 motor vehicles per day (CROW, 2002).

In conclusion, the verge for MRRs is used for encountering and overtaking of vehicles. Criteria have been developed for acceptable traffic volumes to avoid damaging the verge for a given pavement width. The criteria (Figure 3) depend on subsoil and proportion of "heavy" vehicles.

\subsection{Some legal aspects - spatial planning}

For several years, the official public policy in the Netherlands opposed the use of FFBs for purposes that were unrelated to the main functions of the countryside: agriculture, nature and recreation. Only in 2000 did the Fifth Policy Document on Town and Country Planning state that buildings in rural areas that have lost their original functions, such as farm buildings, might be used for residential, sport, business or recreational purposes. With this document a less restrictive planning policy line became formal (Van der Vaart, 2005). Obviously, this line was already practiced on the municipal level since this author found in a 1994 survey that there were hardly any unoccupied FFBs and some were being used for non-agrarian commercial activities. Additionally, in an exploratory study in Ede and Apeldoorn, two extended Dutch municipalities with a large rural area, Sanders (2005) found that FFBs in these areas were also used for a wide range of non-agricultural purposes. However, both municipalities gave themselves only a small amount of time and space for developing a specific policy in this field, and responded to the wishes, questions and complaints of their inhabitants with a reactive spatial and transportation policy that was related to reused FFBs.

In Belgium, differences between spatial reality and preconceived policy goals were also found (Verhoeve et al., 2012): only 140 of the 1015 businesses located in the rural areas with a nonagricultural activity had a full legal position. All of these 'grew historically', being established at a time when no restricting legislation existed.

Recently, the Dutch road capacity standards in Figure 3 were granted formal legal status. The Council of State, the highest court in legal procedures in Dutch spatial planning, set aside a spatial plan for a re-development area in a small village because of "failure to offer a safe access" (Raad van State, 2011). In the plan, traffic flows generated by the new land uses were assigned to existing MRRs. However, when added to existing flows, the expected flows would exceed the present road capacity. Local physical restrictions prohibited a widening of the road pavement. Therefore, the plan was set aside by the council. New alternatives now have to be developed with a lower traffic generation and/or another access. This verdict has broader consequences than the plan in question; for future legal procedures to allow new activities in FFBs in the Netherlands, consequences for rural transportation on MRRs must be considered explicitly and, if necessary, handled to offer 'safe access'. 
In conclusion, spatial legislation governs the legal state of new activities in FFBs. However, spatial legislation and spatial reality seem to be a bit different. In the Netherlands, a recent verdict from the highest court has stipulated the available road capacity as a criterion for allowing a new function in an FFB. As a consequence, road capacity decides the opportunities for developing the countryside.

\subsection{Some examples}

To illustrate how to estimate the new traffic generation and to evaluate it against the actual road capacity, we show five examples of possible new economic functions for FFBs and their generated traffic (Table 2). Each new function is appropriate for the size of the FFB.

\begin{tabular}{|c|l|r|r|}
\hline New economic function & Size & $\begin{array}{l}\text { Trip generation } \\
\text { per unit **) }\end{array}$ & $\begin{array}{l}\text { Trip generation } \\
\text { on FFB }\end{array}$ \\
\hline A. Residence & 1 family & 7 & 7 \\
\hline B. Residence & 3 families & 7 & 16 \\
\hline $\begin{array}{l}\text { C. Administrative/business } \\
\text { office }\end{array}$ & $\begin{array}{l}200 \mathrm{~m}^{2} \text { gross floor } \\
\text { space }\end{array}$ & 8 & 64 \\
\hline $\begin{array}{l}\text { D. Wellness } \\
\text { space }\end{array}$ & 32 & 85 cars \\
\hline $\begin{array}{l}\text { E. Building contractor or } \\
\text { transport }\end{array}$ & $5000 \mathrm{~m}^{2}$ & $\begin{array}{r}170 \text { cars } \\
44 \text { trucks }\end{array}$ & 22 trucks \\
\hline
\end{tabular}

*) The newly generated traffic replaces 5 car trips per day made by the farm family. Volumes of commercial traffic flows remained unchanged as they are now going to neighboring farms instead of an FFB (see section 3.2).

**) See Table 1.

Tab 2. Five examples of new economic functions in FFBs and their estimated traffic generation (trips per day)*

The results show that when an FFB becomes a residence for 1 family, the additional generation is estimated at only $(7-5=) 2$ car trips per day (example A). This generation increases to (21 5 =) 16 when 3 families find their new home on the same FFB (example B). For an office (example C) the new generation is also modest. Wellness, however, is more transport intensive (example D). Not surprisingly, businesses such as transport companies (Figure 4) and building contractors have a much larger impact on road usage because of their higher trip frequency and frequent use of trucks (example E).

When these examples are situated in a clay area alongside a $5.00 \mathrm{~m}$ wide access road with an AADT $=800$ motor vehicles per day, including 14\% "freight traffic" (trucks and agricultural vehicles), the road capacity is about 1080 motor vehicles per day (Figure 3). However, in the case of a transport company or building contractors, the percentage of freight traffic on the road increases by roughly $3 \%$ to $17 \%$ (example E). For $17 \%$ freight traffic, the road capacity decreases to 950 motor vehicles per day. In our example this decreased capacity is still sufficient to absorb the new volume: $800-5$ (the farm family) +85 (cars) +22 (trucks) $=$ 902 motor vehicles per day. However, one should keep in mind that this is the generation of just one FFB. In practice, more FFBs may be established in the area with potentially similar traffic generation. This possibility should be considered simultaneously and preferably synchronically in the area's transportation and spatial planning. 


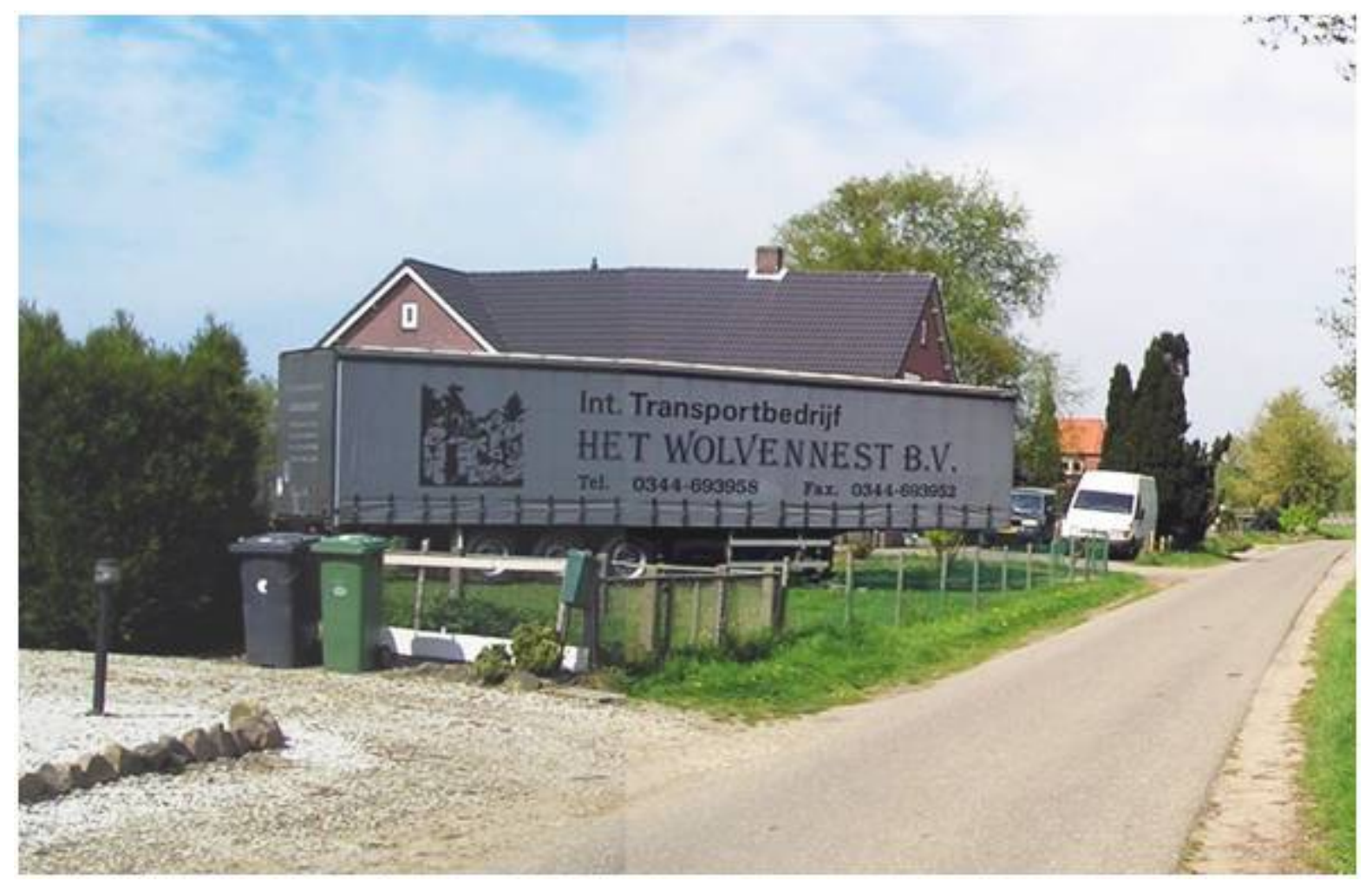

Fig 4. Re-use of an FFB in practice as a transport service. The capacity of the minor rural road seems to be slightly overloaded: the sandy verge on the right-hand side shows initial damage. (Picture: H. J. Sanders).

\section{Discussion and final conclusions}

Rural areas are traditionally connected with agriculture. However, the countryside is becoming a multi-functional space with tourism, especially agritourism, developing on a large scale. On the other hand, the European countryside is developing within the globalization process. This means agricultural production on a much larger scale than before for this area. As a consequence, farm buildings are abandoned and become available for either a residential or another non-agrarian function. In this section we focus on the pros and cons of new functions and missing knowledge in the field of our article.

\subsection{New functions: pros and cons}

Given the continually decreasing number of farm holdings and increasing possibilities for footloose economic activities, a further growth of non-traditional economic functions in the countryside may be expected in the near future. The attempt to use FFBs for these activities should be welcomed. "The direct impact of this new functionality is that the traditional farm buildings survive as cultural heritage... The indirect impact of this is to be found in the regional and local economy, in sustaining social structures in rural areas." (Van der Vaart, 2005: 151). This statement is confirmed by, for example, the state financial aid introduced in France in 1954 to reuse FFBs as accommodation facilities, so-called gîtes rureaux (Sharpley and Vass, 2006). In more densely populated areas, FFBs have even a better potential to suit a different purpose, combined with an increasing demand for real estate in the countryside. However, contrary to the proposal of Van der Vaart (2005), Verhoeve et al. (2012) find just the opposite in practice: an extremely restrictive rural policy, where "[a]ctivities not related to the customary functions of the countryside (i.e., agriculture) are prohibited in most countries, according to the official spatial planning policy" (Verhoeve et al., 2012). As a consequence of a restrictive policy, nonagricultural activities are labeled illegal instead of being welcomed. One should keep in mind that without a new legal function, redundant buildings are threatened by a progressive deterioration and will eventually fall into ruin (Garcia and Ayuga, 2007), whereas reusing these building may preserve cultural heritage and also stimulate the rural economy. Therefore, spatial planning for such situations should start with a discussion on the acceptability of non-agrarian 
functionalities in the countryside in question. This discussion should also include the role of FFBs.

Data for traffic generation show that considerable trip rates are possible, especially for commercial functions. Given the limited capacity of MRRs, the location of such functions should be carefully considered in spatial planning in relationship to the capacity of the access road(s). If road capacity is insufficient, another location for the activity may be preferred to a widening of the road pavement, for both financial and landscape reasons.

For recreational activities, especially on foot or by bicycle, developments of FFBs may be a little paradoxical (Jaarsma and Van Dijk, 2005). Some commercial activities, such as shops, ateliers and catering establishments, increase attractiveness. However, the related motorized traffic flows for provisioning threaten the same attractiveness. This paradox will be even stronger when MRRs need to be widened to offer sufficient technical road capacity; wider roads with their higher volumes are generally less attractive for recreationists on foot or by bicycle.

\subsection{Missing knowledge}

Remarkably, no systematic statistical data are available for the number and character of new economic functions in FFBs. General information on traffic generation can provide trip rates for most of the new functions. However, information on trip rates is missing for a few functions, for example, the hairdressing salon. Further, trip rates for some functions are considered to depend on the facility's location, e.g., in the city center, on the outskirts of a city or in the rural area outside the city. For several functions that can have diverse locations, trip rates in rural areas are still unknown.

The capacity of MRRs is based on damage to the verge. In addition to this technical criterion, an additional criterion deserves further investigation: the acceptable "mix" of motor vehicles, pedestrians and cyclists on MRRs in an attractive "consumption landscape", a multi-functional rural area for recreation and agritourism (Gockel, 2010).

\subsection{Final conclusions}

To explore the ability of the rural road network to absorb newly generated traffic flows on FFBs, we investigated four underlying research questions: the new economic functions of FFBs, their traffic generation, their road network capacity and the role of the FFB in spatial planning. We concluded that quantitative national data on actual new functions are lacking, but we found that redundant farm buildings have been changed to residence or a non-agrarian activity, mostly belonging to the economy's service sector. Traffic generation of these functions can be estimated with standard trip rates. For a residence function, a modest increase of traffic generation with 2 car trips per day is plausible. For other non-agrarian economic functions, generation strongly depends on their type, but some functions, especially a retail and transportation function, will considerably increase local traffic flows. These increases also include flows of freight traffic. The technical capacity of the network of minor rural roads depends on subsoil, total volume and proportion of "heavy" vehicles. Empirical criteria are available for acceptable volumes to avoid damage to the verge. Spatial legislation and spatial reality seem to be a bit different for new activities in FFBs. In the Netherlands, a recent verdict from the highest court has stipulated available road capacity as a criterion for allowing a new function in an FFB.

Finally, abandoned farm buildings are a consequence of enlarging of scale in agriculture. As stated in the introduction, in practice different developments in agriculture are appearing simultaneously: the 'dual agricultural pathway' for Europe (Bindraban and Rabbinge, 2011). To make this situation even more complex, the developments in agriculture are part of a wider development in the countryside (Ilbery, 1998; Murdoch et al., 2003). These developments also affect rural traffic and transportation. Therefore, this paper should be considered as only one part of a series of studies commonly covering the complex field of developing rural traffic and transportation. 


\section{Acknowledgements}

The authors thank Tia Hermans (Alterra, Wageningen UR) for providing the data for Figure 2, Hannes Sanders for providing the picture in Figure 4 and Peter Griffith (Wageningen University, Language Centre) for professional English proofreading.

\section{References}

[1] Bindraban, P. S. \& Rabbinge, R. (2011). European food and agricultural strategy for $21^{\text {st }}$ century. International Journal Agricultural Resources, Governance and Ecology 9(1/2), 80101. Doi: 10.1504/IJARGE.2011.040220.

[2] Birkkjaer, K. O. \& Pedersen, S. (1996). Re-use of old rural buildings in Denmark (pp.139144). In New uses for old rural buildings in the context of landscape planning Proceedings International Seminar of the $2^{\text {nd }}$ Technical Section of CIGR: New uses for old rural buildings in the context of landscape planning. Associazione Italiana di Ingeneria Agraria.

[3] CBS (Centraal Bureau voor de Statistiek) (2007). CBS Landbouwtelling 2006. (Statistic Netherland's Count of Agricultural Activities). Heerlen.

[4] CIGR (Commission International du Genie Rural / International Commission of Agricultural Engineering) (1996). New uses for old rural buildings in the context of landscape planning Proceedings International Seminar of the $2^{\text {nd }}$ Technical Section of CIGR: New uses for old rural buildings in the context of landscape planning. Associazione Italiana di Ingeneria Agraria.

[5] CROW (The national information and technology platform for infrastructure, traffic, transport and public space) (2002). Handboek Wegontwerp: wegen buiten de bebouwde kom. Deel 4. Richtlijnen ontwerp erftoegangswegen. Publicatie 164d. Ede: CROW.

[6] CROW (2007). Verkeersgeneratie woon- en werkgebieden. Vuistregels en kengetallen gemotoriseerd verkeer. Publicatie 256, Ede: CROW.

[7] CROW (2008). Verkeersgeneratie voorzieningen. Kengetallen gemotoriseerd verkeer. Publicatie 272, Ede: CROW.

[8] Flach, A. J. (1966). Ritproduktie van landbouwverkeer in graslandgebieden. [PhD thesis] Wageningen: Agricultural University.

[9] Fuentes, J. M., Gallego, E., Garcia, A. I. \& Ayuga, F. (2010). New uses for old traditional farm buildings: the case of the underground wine cellars in Spain. Land Use Policy 27(3), 738-748. Doi: 10.1016/j.landusepol.2009.10.002.

[10] Garcia, A. I. \& Ayuga, F. (2007). Reuse of abandoned buildings and the rural landscape: The situation in Spain. Transactions of the ASABE 50(4), 1383-1394.

[11] Gockel, R. (2010). Landwirtschaftliche Wege - eine Infrastruktureinrichting für die Zukunft. Schriftenreihe DLKG, Sonderheft 03/2010, 41-43.

[12] Ilbery, B., ed. (1998). The Geography of Rural Change. Harlow: Longman.

[13] ITE (Institute of Transportation Engineers), (1979). Trip Generation, informational report, $2^{\text {nd }}$ edition, Arlington.

[14] Jaarsma, C. F. \& van Dijk, T, (2005). The paradoxical role of infrastructure in the use of metropolitan green areas by urban residents (pp. 186-187). In Voigt, A. \& Kanonier, A.: The dream of a greater Europe. Book of abstracts $19^{\text {th }}$ AESOP congress, July 13/17, Vienna: AESOP.

[15] Jaarsma, C. F., Hermans, C. M. I., de Vries, J. R. \& Rienks W. A. (forthcoming). Multifunctionality in agriculture in a changing countryside: consequences for traffic flows on minor rural roads. 
[16] Jaarsma, C. F., Louwerse, R., Dijkstra, A., de Vries, J. R. \& Spaas, J-P. (2011). Making minor rural road networks safer: The effect of $60 \mathrm{~km} / \mathrm{h}$-zones. Accident Analysis and Prevention 43(4), 1508-1515. Doi: 10.1016/j.aap.2011.03.001.

[17] Jongeneel, R. \& Slangen, L. (.2004). Multifunctionality in agriculture and the contestable public domain in the Netherlands (pp. 183-203). In Brouwer, F., ed., Sustaining agriculture and the rural environment. Cheltenham: Edward Elgar.

[18] Mooy, J. (1981). Capaciteit van plattelandswegen. Utrecht: Government Service for Land and Water Use.

[19] Murdoch, J., Lowe, P., Ward, N. \& Marsden, T. (2003). The differentiated countryside. London: Routledge.

[20] Raad van State (8 November 2011). Uitspraak bestemmingsplan "Woongebied SpaarneBuiten". Accessible from www.rechtspraak.nl/LJN:BU3752.

[21] Rienks, W. A., Galama, P., Hermans, C. M. L. \& Jaarsma, C. F. (2009). Opschaling van melkveehouderij heeft ruimtelijke effecten: kan extra belasting van plattelandswegen worden ondervangen? Spil 257-260(2/3), 31-35.

[22] Robinson, G. M. (2004). Geographies of agriculture: globalisation, restructuring and sustainability. Harlow: Pearson Education.

[23] Sanders, H. J. (2005). Modderige Bermen. Hoe gaan gemeenten om met verkeerseffecten van nieuwe functies in het buitengebied? Een verkenning. [MA thesis] Wageningen University.

[24] Sharpley, R. \& Vass, A. (2006). Tourism, farming and diversification: an attitudinal study. Tourism Management 27(5), 1040-1052 Doi: 10.1016/j.tourman.2005.10.025.

[25] Van der Vaart, J. H. P. (2005). Towards a new rural landscape: consequences of nonagricultural re-use of redundant farm buildings in Friesland. Landscape and Urban Planning 70(1-2), 143-152. Doi: 10.1016/j.landurbplan.2003.10.010.

[26] Verhoeve, A., de Roo N., Rogge, E. (2012). How to visualize the invisible: Revealing re-use of rural buildings by non-agricultural entrepreneurs in the region of Roeselare-Tielt (Belgium). Land Use Policy 29(2), 407-416. 10.1016/j.landusepol.2011.08.005. 